\title{
Internal Migration in Chinese Cities: An Exploration of Youths' Experiences of Delinquency
}

\author{
Jason Hung ${ }^{1}$ \\ ${ }^{1}$ Department of Sociology, the London School of Economics, London, the United Kingdom \\ Correspondence: Jason Hung. E-mail: sociowriting@jasehung.com
}

Received: November 10, 2019

Accepted: January 11, 2020

Online Published: January 31, 2020

doi:10.5539/ass.v16n2p1

URL: https://doi.org/10.5539/ass.v16n2p1

\begin{abstract}
Introduction. In China, urban police tend to arrest and interrogate internal migrants when crimes occur, as they believe migrant cohorts are the main cause of crime. Detecting risk factors in migrant children's delinquency is necessary in order to allow authorities to limit the scope of crime.

Methods. This essay explores studies from Chicago School of Criminology, in additional to other relevant western criminological literature. This essay investigates how poor living conditions, undue levels of fear of crime, deficiency in the formation of social bonds, lack of informal control at home and school, and development of social strain are associated with migrant children's delinquency in China.

Findings. Socioeconomic challenges drive migrant children to delinquency. Migrant children are subject to discrimination and exclusion at school and public spaces, in addition to segregation residentially. The unfair treatment they receive contributes to their inability to develop a metropolitan social bonds and trust. Similarly, migrant parents are victimised by social discrimination, exploitation and exclusion, minimising their opportunities to exercise positive parenting. Their economic hardships impede migrant cohorts from alleviating poverty and increasing community engagement. Local urbanites' fear of crime against migrant cohorts fosters mutual misunderstanding, mistrust and conflicts. Social tension and fear of crime reinforce local urban residents' segregation and discrimination against internal migrants.
\end{abstract}

Conclusions. Migrant children may demonstrate a higher propensity of delinquency than local counterparts. However, more attention should be given to their victimisation as a result of economic hardships and social inequalities, in order to effectively exercise crime control in Chinese cities.

Keywords: youth delinquency, fear of crime, poor living conditions, social control, social bond, social strain

\section{Introduction}

The 2010 Census in China recorded an estimated 260 million internal migrants. The figure constituted 19.4\% of the entire Chinese population. The Census classified internal migrants as citizens working or living beyond their hometowns (Lu, Lin, Vikse, \& Huang, 2016, p. 58). A report from the National Population and Family Planning Commission of China, Department of Services Management of Migrant Population (2012) noted the majority of internal migration - a total of 230 million migrants - were rural-to-urban transplants (Cao, \& Liu, 2015, p. 460). Within this total, 20 million were migrant children aged between 6 and 14, the age range for which China's compulsory education - primary education and junior secondary education - is mandated (Xiao, 2011; Xu, \& Xie, 2015, p. 502). The United Nations International Children's Emergency Fund (UNICEF, 2009) asserted children of rural origin who migrate with their parent(s) to another county or province should be referred to as migrant children (Ma, Hou, Huang, Wang, Li, Zhou, \& Du, 2018, p. 59).

In China, a hukou system was initiated in 1958 to control the movement of the Chinese population (Gallagher et al., 2009, 30; Fan, 2008, p. 66). Under the hukou system, each citizen is assigned either a rural or urban hukou. Those in possession of a rural hukou are denied accessing to most state benefits and opportunities designated for urban Chinese communities (Young, 2013, 28; Davin, 1999, 7; Fan, 2008, 68; Wang, 2005; Chan, \& Zhang, 1999, 81). Despite their social insecurity, numerous push and pull factors foster internal migration. Push factors include low income levels in rural China and a surplus of labour force in rural agricultural industry. Pull factors include broader and more reliable job opportunities, higher urban living standards and better overall life prospects in cities in the long-term (Wang, Zhou, \& Hesketh, 2017, p. 884; Gui, Berry, \& Zheng, 2012, p. 599). 
Beyond economic considerations, internal migration is also part of a cultural repertoire which guides rural communities to explore and develop urban knowledge and metropolitan experiences (Pan, 2018, pp. 190, 193).

As a result of their rural hukou status, internal migrants are dubbed "second-class citizens", a derogatory term which differentiates them from local urbanities (Xiao, 2011). Migrant cohorts are subject to disproportionately poor access to social welfare, including public education, housing pension and medical care (Xiao, 2011; Lu et al., 2016, p. 58). Since the early 1990s, local governments in major cities, including Beijing and Guangdong, began attempts to equalise the social welfare entitlements to residents, irrespective of their hukou status. However, the entrenched distinctions between rural and urban identities remain pronounced $(\mathrm{Hu}, \mathrm{Lu}, \&$ Huang, 2014, p. 2). Internal migrants are restricted to poor working and living conditions, in addition to claiming the least social benefits (Wen \& Lin, 2012, p. 120; Hu et al., 2014, p. 2). For example, although young migrant labours are more ambitious in the respect of upward social mobility, often are they situated in the secondary labour market with poor job prospects (Pan, 2018, p. 187). These young labours are absorbing physically demanding jobs in factories, as well as the service and construction industries, which local urban dwellers disdain (Wong, Chang, He, \& Wu, 2010, p. 816). Additionally, the migrant populations are usually residentially segregated and concentrated in overcrowded and poorly facilitated neighbourhoods of so-called "urban villages" (Lu et al., 2016, p. 59; Xiao, 2011).

The distinct lifestyles between migrant cohorts and local urbanites engender continual cultural conflicts and misunderstandings, further marginalising the former group (Wong et al., 2010, p. 816). While enrolment into local schools can help migrant children realise cultural appropriation, very often are they segregated from local urban students for schooling (Song, Zhu, Xia, \& Wu, 2014). Segregation refers to a phenomenon where individuals or places are separated from one another, with an implication that such a separation is based on classification or differentiation of race, class or otherwise (Muncie, Talbot, \& Walters, 2009, p. 38). Since migrant children are not regarded as local urbanites, they are required to pay expensive entrance fees for local public schools - schools which disproportionately dominate most educational resources (Xiao, 2011; Lu et al., 2016, p. 60; Pan, 2018, p. 363). The annual entrance fees ranged from RMB $\$ 3,000$ to RMB30,000 per child (Wong, Chang, \& He, 2009, p. 816; Lu et al., 2016, p. 60). In response, the migrant population established unlicensed, poorly-conditioned migrant schools to accommodate and educate migrant children, where teacher quality and teaching facilities are usually unsatisfactory (Xiao, 2011; Qian, 2017, p. 212; Song et al., 2014, p. 359). Poor schooling conditions adversely affect migrant children's academic outcomes. Those with the lowest socioeconomic status (SES) receive the least academic support at school and home, and exhibit the worst academic performance (He et al., 2014, p. 474; Song et al., 2014). Their academic outcomes are further worsened, as migrant children encounter alienation and misunderstanding by their teachers, a set of setbacks which make them more likely to leave school prematurely (Wong et al., 2010, p. 821). Dropout rates among migrant children reach as high as 9.3\%, almost triple the average dropout rates nationwide (3.3\%) (Xiao, 2011).

Most migrant parents are typically working between 12 and 15 hours per day due to the lack of protection of employment contracts (ibid). Their working conditions and poor educational background facilitate an inability to provide sufficient emotional, intellectual and financial support for their children, further restricting the academic performance and possibilities of the latter (ibid). The lack of parental support and supervision, in addition to constant experiences of social isolation and discrimination, also exacerbate migrant children's development of social strain (Wong et al., 2009, p. 816; Wong et al., 2010, p. 145). Social strain is defined as negative interpersonal interactions which lead to distress, rather than enhanced wellbeing (Chen \& Feeley, 2014, p. 142; Lunsky \& Benson, 2001, p. 107). An increase in social strain is associated with migrant children's behavioural problems and delinquency (Wong et al., 2009, p. 133; Wen \& Lin, 2012, p. 122; Meng \& Yamauchi, 2017, p. 1679). Here delinquency includes violent crimes and drug use (Luo, Tong, \& Cheung, 2018, p. 248).

Since migrant parents regularly change worksites due to little job security, their children have to change schools occasionally. A frequent change in residence bars migrant children from experiencing a positive peer and teacher relationship. The lack of social bonds at school impedes school attainment and psychosocial wellbeing of migrant children. They are inclined to suffer from obsession-compulsion, interpersonal sensitivity, anxiety and hostility (Wong et al., 2009, pp. 816-7, 820). Broken social bonds play an important role in migrant children's delinquent behaviours (Luo et al., 2018, p. 248; Wen \& Lin, 2012, p. 134). Migrant children with few academic achievements and early dropouts also have a propensity to become behaviourally problematic and antisocial, and even engage in criminal acts (Pan, 2018, p. 196).

\section{Essay Aims}

In China, urban police officers are inclined to arrest and interrogate internal migrants when crimes occur, as they 
believe migrant cohorts are the main cause of crime and safety problems (Chen, Stanton, Kaljee, Fang, Xiong, Lin, Zhang, \& Li, 2011, p. 27). Both urban police officers and residents in major cities, including Beijing and Zhejiang, argue crime control over internal migrant communities is a primary strategy to maintain social order and decrease urban crime rates (Han, 2008, p. 600; Pan, 2018, p. 196). Sheldon Glueck and Eleanor Glueck argue career criminals begin offending at a very early age and crime declines significantly with age (Sampson \& Laub, 1993, p. 35). Detecting risk factors in migrant children's delinquency is necessary in order to allow authorities to limit the scope of crime and disorders (Body-Gendrot, 2013, p. 235). Aiming to identify and explain major risk factors in Chinese migrant children's delinquent behaviours, this essay explores a set of studies from Chicago School of Criminology, in additional to other relevant western criminological literature. The Chicago School of Criminology is a body of research emerging in early $20^{\text {th }}$ century, which specialises in urban sociology and, in part, addresses how a spectrum of social conditions rather than racial compositions contribute to noteworthy crime rates in some Chicago neighbourhoods (e.g. Shaw \& McKay, 2006; Body-Gendrot, 2012; Wacquant, 2008; Sampson, 2012). This essay investigates how overcrowded and poor living conditions, undue levels of fear of crime, deficiency in the formation of social bonds, lack of informal control at home and school, and development of social strain are associated with migrant children's delinquency in China.

\section{Overcrowded and Poor Living Conditions}

As relative to rural regions, migrant cohorts living in cities enjoy modern utility infrastructure, including a stable supply of tap water, electricity and cooking gas, and convenient transportation network (Xu \& Xie, 2015, p. 504). However, in order to live in low-cost accommodation, migrant families are predominantly restricted to residentially segregated and excluded, overcrowded living environments in "urban villages" (Guo, Ren, Wang, Qu, Zhou, Ran, Wang, \& Hu, 2015; Wen \& Lin, 2012, p. 120; Wong et al., 2009, p. 816; Lu et al., 2016, p. 59). The rest of migrant cohorts live in poorly-equipped factory dormitory or construction sites, which are also subject to overcrowded living conditions (Xiao, 2011, p. 2). Due to internal migration, migrant children are removed from the familiarity of rural communities and placed in distinct urban living environments, increasing their risks to develop distress (Wang, 2017, p. 640).

In America, for example, in Appalachia and Mississippi Delta, impoverished cohorts are likely to live in poor, increasingly segregated cities (Lichter et al. 2012, p. 383). Their neighbourhoods are associated with inadequate access to sanitation, poor structural quality of housing, overcrowding and lack of social security (Muncie et al., 2009 , p. 52). The poor disproportionately concentrate in impoverished neighbourhoods as accommodation is affordable. Alternatively, better-off individuals are inclined to segregate themselves in wealthy, better-developed areas, leaving the poor behind in declining communities (Lichter et al., 2012, p. 366). Alongside the existence of class segregation, racial segregation in some cities has been salient - where poor African Americans are mostly segregated from poor whites (Lichter et al., 2012, pp. 366, 378; Herbert \& Grobelski, 2014).

An example of racial and class segregation was the emergence of African American ghettos in cities since 1890, followed by their expansion between 1940 and 1970 (Cutler, Glaeser, \& Vigdor, 1997). In the mid-20 $0^{\text {th }}$ century, America experienced the segregation of low-income, disadvantaged African Americans' communities within ghettos in cities (Wacquant, 2008, pp. 45, 59). Those inhibiting ghettos are segregated by race, language, income and social status, rather than through choices of free will or positive attraction to others akin to themselves (Wirth, 2011, p. 120). The structure of African Americans' ghettos resembles that of "urban villages" in Chinese cities, where Chinese migrant cohorts concentrate in residential areas based on their low social status and financial constraints. Residential segregation fosters social marginalisation against disadvantaged, isolated communities. In African Americans' ghettos, spatial disgrace affects the perceptions and behaviours of different parties. For example, companies discriminate against individuals if the former learns the latter invests or lives in ghetto areas. Law-enforcement officers often communicate or treat ghettos' inhabitants in a discourteous manner (Wacquant, 2016, p. 1083). Commercial or residential addresses can therefore serve as symbols to differentiate social status of individuals. The identification of areas of residence may possibly engender discrimination and exclusion against migrant families in China.

In America, living in socioeconomically deprived ghettos are associated with the emergence of social disorders, including the prevalence of drug markets (Maguire, Morgan, \& Reiner, 2012, p. 462). While African Americans' communities are concentrated in the areas with high rates of delinquency, this does not necessarily imply a higher delinquent and criminal proclivities among African American populations. Sophie Body-Gendrot (2012, p 149) argues individuals who are forced to live in areas with poor access to daily necessities and little ability to organise against such socioeconomic dilemmas are factors which foster high rates of delinquency. It is therefore essential to raise the standard of living of communities in order to efficiently control urban delinquency 
(Body-Gendrot , 2001, p. 921). Using data from the 1990 and 2000 U.S. Census Summary Files, and from the 2005 to 2009 American Community Survey, Daniel Lichter, Domenico Parisi and Michael Taquino (2012, pp. $363,383)$ and Loic Wacquant $(2008$, p. 75$)$ argue the racial and class segregation of impoverished African Americans, and other minorities, restricts their opportunities for upward social mobility through spatial mobility, leading to an uneven distribution of employment, education and wealth-accumulation. As a result, spatially-isolated, disadvantaged minorities tend to experience intergenerational poverty. Li Shi, Luo Chuliang and Terry Sicular (2013) also found similar associations between spatial segregation against migrant populations and experience of intergenerational poverty in Chinese contexts. Yuting Liu and Fulong Wu (2006, pp. 610, 624) further argue "urban villages" are the key poverty concentration areas in China, in which concentration of poverty is a main cause of crime.

\section{Fear of Crime}

For neighbourhoods of higher socioeconomic status, spatial segregation is seen as a means of security, in order to minimise fear of crime prompted by encountering individuals who are perceived to have distinct and inferior social, cultural, racial and economic profiles (Muncie et al., 2009, p. 66). Fear of crime is an emotional response - in the form of discomfort, anxiety, apprehension and panic - to crime or symbols associated with crime (Body-Gendrot, 2013, p. 223; Brands, Schwanen, Aaist, 2013, p. 441). However, a result of spatial segregation is the aggravation of mutual misunderstanding and miscommunication between communities. Fear of crime is then increased if interactions between inhabitants from different neighbourhoods become necessary (ibid). In Chicago's ghettos, the segregation of individuals by race and occupation often facilitates racial antagonisms and class conflicts (Park, 1925, p. 10).

However, a certain level of fear of crime serves as a positive warning signal against danger, and hence, an ultimate crime control tool (Body-Gendrot, 2012, pp. 3, 23; Downes \& Rock, 1996 [1988], pp. 112, 241). In African American ghettos in Chicago, the development of fear of crime prompts residents to barricade heavy mental gates and burglar bars behind windows and doors of accommodations, and avoid going to parks especially after nightfall. Buses of the Chicago Transit Authority running routes are escorted by police squad cars to discourage assaults and violent crimes (Muncie et al., 2009, p. 55). An alertness to potential crimes and self-protection against crime demonstrate how some degree of fear of crime effective facilitates crime control.

Nevertheless, an undue level of fear of crime intensifies mistrust between neighbours, decreases the efficacy of mutual support, deteriorates social relations and undermines informal social controls - a key strategy to reduce youths' delinquency (Urbanik, Thompson, \& Bucerius, 2017, p. 430). In Regent Park, a neighbourhood located in downtown Toronto, when the relationship between residents is strained, very often fear of crime and mistrust aggregate, until a level where collective efforts and involvement to maintain social order and combat crimes are reduced (ibid). Body-Gendrot (2013, p. 226) has also found that the lack of social understanding among residents or between residents and law enforcement authorities contributes to a shortage of community-based social control, and therefore, higher crime rates. Here Chinese literature does not find local urban dwellers exhibiting crime prevention strategies akin to African American's ghettos in Chicago by, for example, installing heavy metal gates at home. However, Daniel Wong, Chang Li and He Song (2007), Yuan Ren (2006) and Yao Xiao (2011) demonstrate local Chinese city dwellers often blame migrant populations for upsetting social orders and increasing crime rates, leading to a significant level of interpersonal conflicts and misunderstanding, and social exclusion against, and the avoidance of everyday encounters with, migrant cohorts.

\section{Social Bonds}

Living in disadvantaged, isolated urban areas, migrant children have to endure the loss, or decline, in social bonds (Luo et al., 2018, p. 249). Internal migration causes the loss of social contacts with friends and families from their rural origin. In addition, migrant children have a propensity of concealing or denying their identity of rural origin in order to increase opportunities to establish social contacts with local urban children (Yuan, Fang, Liu, Hou, \& Lin, 2013, p. 362). However, they remain subject to regular social discrimination and exclusion at the hands of urban children due to visible symbols of rural origin identity, for example, in the forms of heavy rural accents and out-of-date clothing (Luo et al., 2018, p. 250; Wong et al., 2010, p. 145). Social discrimination and exclusion bar migrant children from building a peer network in cities (Luo et al., 2018, p. 250).

Migrant children suffering from poor social support are disinclined to explore and expand their social network, which in turn limits their opportunities to gain additional social support in future $(\mathrm{Ni}$, Chui, Ji, Jordan, \& Chan, 2016, p. 755). The fewer social connections migrant children secure, the more negative self-values they develop and the less resilience they can establish. Experiences of continual separation and exclusion from, and conflicts with, teachers, peers, parents or otherwise curtail their social bonds and diminish their application of effective 
coping strategies under stressful circumstances (Guo et al., 2015, p. 83).

The quality of relationships with parents is arguably the most significant determinant of migrant children's self-values. Here the quality of a relationship is measured by parental acceptance and support, and parent-child communications. Migrant children who live with a single parent in cities, or experience poor contacts with their migrant parents due to long working hours, face greater impediments to the construction of self-values and concepts (Liu, Sun, Zhang, Wang, \& Guo, 2010). Weakening parental contact is positively associated with experiences of stressful circumstances, including economic hardship and perceived discrimination (Luo et al., 2018, p. 249). Though telecommunication enables long-distance parenting and maintains parent-child bonds, an absence or low levels of in-person parental support, guidance and supervision in migrant children's everyday life undermines parent-child relationships (Luo et al., 2018, p. 260; Wen \& Lin, 2012, p. 121).

Poorer parent-child, teacher-student and peer relationships are associated with lower retention rates, poorer academic outcomes and worse mental wellbeing of migrant children (Liao \& Zhang, 2014, p. 1588; Wong et al., 2009, p. 817). Migrant children with fewer mental resources have a diminished capacity to manage adverse circumstances, displaying more behavioural problems (Hu et al., 2014, p. 8). In Wuhan - the capital city of Hubei Province in central China - for example, migrant children who experience more behavioural problems demonstrate significantly more emotional problems, conduct problems, hyperactivity and inattention, and worse peer relationship (Lu et al., 2017, p. 54). Additionally, worse interpersonal relationships undermine migrant children's adherence to moral and disciplinary norms, increasing their experiences of delinquency (Luo et al., 2018, p. 248).

According to Travis Hirschi's (1969, p. 16) Social Bond Theory, delinquency results when individuals suffer from weakening or broken social bonds. Hirschi reduces social bonds to four components: attachment, commitment, involvement and belief. Attachment means individuals should care about wishes, expectations and the opinions of others (Downes \& Rock, 1996 [1988], p. 245). Migrant children suffer from distancing social relationships with their left-behind rural families and friends, migrant parents and urban peers and teachers. They are therefore deprived of the rights to concern for others. Commitment refers to law abiding for the purposes of avoiding risks to lose their acquired goods, reputations and prospects (ibid). Migrant children are entitled to the least amount of social welfare and resources in cities, they are, therefore, associated with a minimum level of risks if they fail to abide by laws. Involvement is understood as individuals who are occupied to finish conventional things, leaving them no spare time to engage in deviant behaviours (ibid, p. 246). Migrant children display disproportionately high early dropout rates, leading to excessive amount of spare time and creating the potential to exercise delinquency (Xiao, 2011). Belief is interpreted as the extent to which individuals believe they should obey societal rules and norms. Suffering from unsatisfactory interpersonal relationships reduces migrant children's obedience of these rules and norms, increasing the likelihood of which they will engage in delinquently (Luo et al., 2018, p. 248).

In societies, the enjoyment of social trust and use of social infrastructure, including parks and local shops, strengthens social bonds between residents (Body-Gendrot, 2012, p. 39; Leyden, Goldberg, \& Michelbach, 2011, p. 873). However, migrant cohorts' encounters of regular discrimination and antagonism, in addition to the denial of access to public spaces, minimise their possession and use of social trust and infrastructure respectively (Sampson, 2012, p. 6; Wen \& Lin, 2012, p. 120; Guo et al., 2015). Poor social trust is an indicator of weak social bonds, and therefore, high delinquent rates (Body-Gendrot, 2012, pp. 10-1). Body-Gendrot (2013, p. 229) argues individuals are less likely to develop social trust when facing economic disadvantages and inequalities. Migrant children constantly experience socioeconomic disadvantages and inequalities, further limiting their opportunities to develop social trust in cities. Additionally, John Muncie, Deborah Talbot and Reece Walters (2009, p. 51) claim youths deprived of the access to public spaces are less able to communicate and integrate with others, leading to symptoms of isolation, intellectual underdevelopment and antisocial behaviours. Such an argument corresponds with relevant Chinese literature, which associates migrant children's lack of access to public spaces with their demonstration of antisocial behaviours (Pan, 2018, p. 196; Wang et al., 2017, p. 888).

\section{Informal Social Control}

After internal migration, parents become the major, and sometimes the only, source of social support for migrant children. Positive parenting is negatively associated with migrant children's development of psychological and behavioural problems (Zhao et al., 2015, p. 542). Here positive parenting refers to the parental provision of love, support and understanding for children, alongside parental monitoring and supervision to guide children's behaviours (Wen \& Lin, 2012, p. 133). Positive parenting encapsulates a range of family socialisation, including emotional and informational support and effective parent-child communications. These forms of family 
socialisation are positively related to migrant children's school involvement (ibid). Constant parent-child communications and parental supervision are crucial to help migrant children develop positive moral values, minimising their opportunities to engage in deviant behaviours, such as involvement in youth gang activities (Zhao et al., 2015, p. 543).

However, a broken family, including a single parent family and parental absence, often discourages the delivery of positive parenting for migrant children. Here parental absence happens as migrant parents are subject to disproportionately long working hours (Wen \& Lin, 2012, pp. 121-2; Luo et al., 2018, p. 250). Single parent families have a propensity for weaker parental supervision, support and guidance, and looser parent-child bonds, increasing the likelihood of migrant children to partake in delinquent behaviours (Luo et al., 2018, p. 248; Wen $\&$ Lin, 2012, p. 122). Migrant parents under stress often apply coercive and violent parenting, further limiting migrant children's entitlement to parental care and support (Luo et al., 2018, p. 250). When positive parenting is attenuated, migrant children are more susceptible to delinquent peer pressure (ibid). When compared with their local urban counterparts, migrant children are significantly more likely to cheat on exams, steal others' property, suffer from bullying and dropout early, in part, due to the lack of parental supervision and care. Early dropouts are associated with migrant children's exhibition of risk behaviours, including smoking and drinking alcohol (Wang et al., 2017, p. 889).

Positive parenting is associated with migrant children's school attainment and engagement, prompting the chance to receive care, mentorship and discipline from teachers (Chen, Adams, Qu, Wang, \& Chen, 2013, p. 717). At migrant school, teachers divide migrant children into either "good student" or "bad student" classes. Those assigned into "good student" and "bad student" classes are perceived as well-behaved and disciplinarily problematic migrant children respectively (Pan, 2018, p. 195). In "bad student" classes, teachers rarely require migrant students to assume student responsibilities, allowing students to be absent from school, failing in handing homework on time, and sleeping, eating and playing in class (ibid). These students are less committed to school engagement and given fewer opportunities to develop appropriate moral values and disciplinary behaviours.

Robert Sampson and John Laub (1993, p. 101) argue socialisation by both families and schools are prominent factors in informal social control. Here informal social control is the workings of mundane interactions among city dwellers as forms of control through collective punishment, enforced by agents other than state authorities (Herbert, \& Grobelski, 2014). Hirschi (1968, 1983), Michael Gottfredson and Travis Hirschi (1990), Gerald Patterson (1980, 1982), John Hagan (1989), John Braithwaite (1989) and Rolf Loeber and Magda Stouthamer-Loeber (1986) emphasise that familial functionality requiring parent-child contact is the primary deterrent in juvenile delinquency. Lober and Stouthamer-Loeber's (1986, p. 29) meta-analysis further demonstrates regular practice of parental rejection and lack of parental supervision are strongest predictors of juvenile misconduct and delinquency (Sampson \& Laub, 1993, p. 65; Downes, \& Rock, 1996 [1988], p. 247). As part of the Unravelling Juvenile Delinquency (UJD) project, Sheldon Glueck and Eleanor Glueck (1950) studied 500 delinquent and 500 non-delinquent males, all aged between 10 and 17, in Massachusetts. They identified familial supervision, attachment and discipline are the key factors in curbing delinquent behaviours (Sampson \& Laub, 1993, p. 96). This literature supports relevant Chinese studies, reinforcing the importance of positive parenting in minimise migrant children's delinquent behaviours.

The UJD project also revealed that negative maternal and especially paternal parenting, such as aggressive, threatening and punitive parenting approaches, were associated with youths' exhibition of early misbehaviours and delinquency (Sampson \& Laub, 1993, pp. 36, 91). Here findings from the UJD project echoes Weixiang Luo et al.'s (2018, p. 25) argument in the respect that coercive and violent parenting of migrant children facilitates their delinquent performance.

\section{Social Strains}

Robert Agnew's (1992) General Strain Theory (GST) goes beyond the proposition of weak, or absent, informal social control and draws a casual association between roles of negative situations and delinquency. The theory addresses the failure to achieve positively valued goals, removal of positively valued stimuli, and experiences of negative stimuli leading to negative emotional and psychological effects prompt individuals to act delinquently in order to alleviate these strains. Negative emotional and psychological effects include anger, anxiety and depression (Luo et al., 2018, p. 249). In African American's ghettos in Chicago, impoverished communities encounter, on a daily basis, racial and class segregation, discrimination, limited employment and school opportunities, slim chances for wealth accumulation. These experiences are all examples of a denial to achieve positive goals and access to positive stimuli, and a boost of exposure to negative stimuli (Wacquant, 2008, p. 75). 
Likewise, migrant children are subject to overcrowded, poor and segregated living conditions, economic hardship, lack of access to public spaces, little entitlement to social welfare, experiences of constant social and school discrimination and exclusion, lack of positive parenting, poor self-values and weak self-concepts, and acculturation and urban adjustment difficulties. According to the GST, these social strains are predictors of migrant children's hostility, depressive symptoms, and delinquent and criminal behaviours (Luo et al., 2018, pp. 249-50, 260; Wong et al., 2009, p. 817; Ni et al., 2016, p. 755; Lu et al., 2016, p. 65).

\section{Conclusion}

While local urbanites criticise internal migrants in China for their high levels of delinquent and criminal behaviours, there is no evidence to suggest that internal migration per se is associated with delinquency or criminality. Existing literature suggests socioeconomic challenges drive migrant children to delinquency. Migrant children are subject to discrimination and exclusion at school and public spaces, in addition to segregation residentially. The unfair treatment they receive in cities contributes to their inability to develop a metropolitan social network, bonds and trust. Similarly, migrant parents are also victimised by social discrimination, exploitation and exclusion, minimising their opportunities to exercise positive parenting, including the provision of parental support. Their economic hardships impede migrant cohorts from realising upward social mobility, a crucial factor in poverty alleviation, prevention from social marginalisation and increase in community engagement. In part due to the association between migrant communities and high crime rates, local urbanites' fear of crime against migrant cohorts fosters mutual misunderstanding, mistrust and conflicts. Existing literature does not indicate that local city dwellers sympathise with the socioeconomic difficulties migrant cohorts experience. Instead, studies suggest social tension and fear of crime reinforce local urban residents' segregation and discrimination against internal migrants.

Socioeconomic challenges encountered by migrant cohorts constitute human rights abuses. According to Article 7 and 23 (1) (2) of Universal Declaration of Human Rights (UNHR), migrant parents should be entitled to fair and just choices of employment and favourable working conditions with occupational security (United Nations, 1948). Enjoying fairer job opportunities and better working environment increase the social security migrant cohorts possess, in addition to entitling these them to stronger social bonds with wider populations. As a result, migrant children might suffer from less social strain, more social commitments, and, therefore, lower risks of delinquency.

Alternatively, migrant children should be given equal educational opportunities as their local urban counterparts, a right that is stipulated in Article 26 of UNHR, Article 28 of Convention on the Rights of the Child and Article 9 and 36 of Education Law of the People's Republic of China (Xiao, 2011). Migrant children might demonstrate a higher propensity of delinquency than local counterparts. However, more attention should be given to their victimisation as a result of human rights violation, economic hardships and social inequalities. With more equal educational opportunities and levels of social control, migrant cohorts might display lower dropout rates and better disciplines. To effectively exercise crime control in Chinese cities, local governments and judicial authorities should ensure migrant cohorts are entitled to fair and just treatment as per relevant human rights laws, a strategy which can help enhance socioeconomic entitlements to migrant communities. The more equal and better socioeconomic wellbeing migrant cohorts can enjoy, the more local Chinese governments can control crime rates in cities.

\section{References}

Body-Gendrot, S. (2001). The Politics of Urban Crime. Urban Studies, 38(5-6), 915-928. https://doi.org/10.1080/00420980125533.

Body-Gendrot, S. (2012). Old and New Fears in Cities. Globalisation, Fear and Insecurity: The Challenges for Cities North and South (pp. 21-39). London: Palgrave Macmillan.

Body-Gendrot, S. (2013). Place, Space and Urban (in) Security. In K. Kerezsi, \& R. Lévy (Eds.), The Routledge Handbook of European Criminology (pp. 222-240). London: Routledge.

Braithwaite, J. (1989). Crime, Shame and Reintegration. Cambridge: Cambridge University Press.

Brands, J. et al. (2013). Fear of Crime and Affective Ambiguities in the Night-Time Economy. Urban Studies, 52(3), 439-55. https://doi.org/10.1177/0042098013505652.

Cao, Y., \& Liu, Z. (2015). Poverty and Health: Children of Rural-to-Urban Migrant Workers in Beijing, China. Social Indicators Research, 123(2), 459-477.

Chan, K., \& Zhang, L. (1999). The Hukou System and Rural-Urban Migration in China: Processes and Changes. 
The China Quarterly, 160(4), 818-55. https://doi.org/10.1017/S0305741000001351.

Chen, S. et al. (2013). Parental Migration and Children's Academic Engagement: The Case of China. International Review of Education, 59(6), 693-722. https://doi.org/10.1007/s11159-013-9390-0.

Chen, X. et al. (2011). Social Stigma, Social Capital Reconstruction and Rural Migrants in Urban China: A $\begin{array}{lllll}\text { Population Health } \quad \text { Perspective. } & \text { Hum }\end{array}$ https://doi.org/10.17730/humo.70.1.k76047734m703500

Chen, Y., \& Feeley, T. (2014). Social Support, Social Strain, Loneliness, and Wellbeing Among Older Adults: An Analysis of the Health and Retirement Study. Journal of Social and Personal Relationships, 31(2), 141-61. https://doi.org/10.1177/0265407513488728

Cutler, D. et al. (1997). The Rise and Decline of the American Ghetto. NBER Working Paper No. 5881. https://doi.org/10.1086/250069

Davin, D. (1999). Internal Migration in Contemporary China. New York, NY: Macmillan Press Ltd.

Downes, D., \& Rock, P. (1996 [1988]). Understanding Deviance: A Guide to the Sociology of Crime and Rule Breaking. Oxford: Clarendon Press.

Fan, C. (2008). Migration, Hukou and the City. In S. Yusuf, \& T. Saich (Eds.), China Urbanizes: Consequences, Strategies and Policies: Directions in Development Countries and Regions (pp. 65-89). Washington, DC: The World Bank.

Gallagher, M. et al. (2009). OECD Review of Tertiary Education: China. Paris: OECD Publishing.

Glueck, S., \& Glueck, E. (1950). Unravelling Juvenile Delinquency. Cambridge, MA: Harvard University Press.

Gottfredson, M., \& Hirschi, T. (1990). A General Theory of Crime. Stanford, CA: Stanford University Press.

Gui, Y. et al. (2012). Migrant Worker Acculturation in China. International Journal of Intercultural Relations, 36(4), 598-610. https://doi.org/10.1016/j.ijintrel.2011.11.007.

Guo, J. et al. (2015). Depression Among Migrant and Left-Behind Children in China in Relation to the Quality of Parent-Child and Teacher-Child Relationships. PLoS ONE, 10(12). https://doi.org/10.1371/journal.pone.014560.

Hagan, J. (1989). Structural Criminology. New Brunswick, NJ: Rutgers University Press.

Han, D. (2008). Policing and Racialisation of Rural Migrant Workers in Chinese Cities. Ethnic and Racial Studies, 33(4), 594-610. https://doi.org/10.1080/01419870903325651

He, J. et al. (2014). Prevalence and Causes of Visual Impairment and Rate of Wearing Spectacles in Schools for Children of Migrant Workers in Shanghai, China. BMC Public Health. https://doi.org/10.1186/1471-2458-14-1312.

Herbert, S., \& Grobelski, T. (2014). Dis/Order and the Regulation of Urban Space. In R. Paddison, \& E. McCann (Eds.), Cities and Social Change: Encounters with Contemporary Urbanism (pp. 128-42). London: SAGE. https://doi.org/10.4135/9781473907867.n7.

Hirschi, T. (1968). The Nature of Methodological Criticism. In T. Hirschi, \& H. Selvin (Eds.), Delinquency Research: An Appraisal of Analytic Methods (pp. 1-34). New York: NY: Routledge.

Hirschi, T. (1983). Age and the Explanation of Crime. American Journal of Sociology, 89(3), 552-84. https://doi.org/10.1086/227905.

$\mathrm{Hu}, \mathrm{H}$. et al. (2014). The Psychological and Behavioural Outcomes of Migrant and Left-Behind Children in China. Children and Youth Services Review, 46(C), 1-10. https://doi.org/10.1016/j.childyouth.2014.07.021.

Leyden, K. et al. (2011). Understanding the Pursuit of Happiness in Ten Major Cities. Urban Affairs Review, 47(6), 861-88. https://doi.org/10.1177/1078087411403120.

Li, S. et al. (2013). Overview: Income Inequality and Poverty in China, 2002-2007. In S. Li, H. Sato, \& T. Sicular (Eds.), Rising Inequality in China: Challenges to a Harmonious Society (pp. 24-132). Cambridge: Cambridge University Press. https://doi.org/10.1017/CBO9781139035057.004.

Liao, C., \& Zhang, J. (2014). Measuring the Sense of Security of Children Left Behind in China. Social Behaviour and Personality, 42(10), 1585-602. https://doi.org/10.2224/sbp.2014.42.10.1585.

Lichter, D. et al. (2012). The Geography of Exclusion: Race, Segregation, and Concentrated Poverty. Social Problems, 59(3), 364-88. https://doi.org/10.1525/sp.2012.59.3.364. 
Liu, L. et al. (2010). A Survey in Rural China of Parent-Absence Through Migrant Working: The Impact on Their Children's Self-Concept and Loneliness. BMC Public Health, 10(32). https://doi.org/10.1186/1471-2458-10-32.

Liu, Y., \& Wu, F. (2006). Urban Poverty Neighbourhoods: Typology and Spatial Concentration Under China's Market Transition, A Case Study of Nanjing. Geoforum, 37(4), 610-24. https://doi.org/10.1016/j.geoforum.2005.11.006.

Loeber, R., \& Stouthamer-Loeber, M. (1986). Family Factors as Correlates and Predictors of Juvenile Conduct Problems and Delinquency. In M. Tonry, \& N. Morris (Eds.), Crime and Justice (pp. 29-149). Chicago, IL: University of Chicago Press. https://doi.org/10.1086/449112.

$\mathrm{Lu}$, S. et al. (2016). Well-Being of Migrant and Left-Behind Children in China: Education, Health, Parenting and Personal Values. International Journal of Social Welfare, 25(1), 58-68. https://doi.org/10.1111/ijsw.12162.

Lu, S. et al. (2017). Mindfulness and Academic Performance: An example of Migrant Children in China. Children and Youth Services Review, 82(1), 53-9. https://doi.org/10.1016/j.childyouth.2017.09.008.

Luo, W. et al. (2018). Rural-to-Urban Migration and Adolescent Delinquent Behaviours: Evidence from Hunan and Guangdong in China. Eurasian Geography and Economics, 59(2), 246-66. https://doi.org/10.1080/15387216.2018.1496346.

Lunsky, Y., \& Benson, B. (2001). Association Between Perceived Social Support and Strain, and Positive and Negative Outcome for Adults with Mild Intellectual Disability. Journal of Intellectual Disability Research, 45(2), 106-14. https://doi.org/10.1046/j.1365-2788.2001.00334.x.

Ma, Y. et al. (2018). Educational Inequality and Achievement Disparity: An Empirical Study of Migrant Children in China. Children and Youth Services Review, 87(1), 145-53. https://doi.org/10.1016/j.childyouth.2018.02.026.

Maguire, M et al. (2012). The Oxford Handbook of Criminology. Oxford: Oxford University Press.

Meng, X., \& Yamauchi, C. (2017). Children of Migrants: The Cumulative Impact of Parental Migration on Children's Education and Health Outcomes in China. Demography, 54(5), 1677-714. https://doi.org/10.1007/s13524-017-0613-z.

Muncie, J. et al. (2009). Crime: Local and Global (pp. 37-70). Cullompton: Willan Publishing.

Murphy, R. (2014). Study and School in the Lives of Children in Migrant Families: A View from Rural Jiangxi, China. Development and Change, 45(1), 29-51. https://doi.org/10.1111/dech.12073.

Ni, S. et al. (2016). Subjective Wellbeing Amongst Migrant Children in China: Unravelling the Roles of Social Support and Identity Integration. Child: Care Health and Development, 42(5), 750-758. https://doi.org//10.1111/cch.12370.

Patterson, G. (1980). Mothers: The Unacknowledged Victims. Chicago, IL: University of Chicago Press.

Patterson, G. (1982). Coercive Family Process. Eugene, OR: Castalia Publishing Company.

Pan, L. (2018). From Left-Behind Children to Young Migrants: The Intergenerational Social Reproduction of Rural Migrant Labour in China. Eurasian Geography and Economics, 59(2), 184-203. https://doi.org/10.1080/15387216.2018.1484298.

Park, R. (1925). The City: Suggestions for the Investigation of Human Behaviour in the Urban Environment. The City (pp. 1-46). Chicago, IL: The University of Chicago Press.

Ren, Y. (2006). Globalization and Grassroots Practices: Community Development in Contemporary Urban China. In F. Wu (Eds.), Globalization and the Chinese City (pp. 292-310). London: Routledge.

Qian, L. (2017). Three Types of Social Integration Status among Children of Migrant Workers in China: Scenes of Superiority of City Residents, Co-Existence of Urban Culture and Rural Hometown Culture, and Weak Social Capital under Strong Policy Discourse. Chinese Education \& Society, 50(4), 393-408. https://doi.org/10.1080/10611932.2017.1382132.

United Nations. (1948). Universal Declaration of Human Rights. Retrieved from https://www.un.org/en/universal-declaration-human-rights/

Urbanik, M. et al. (2017). Before There Was Danger but There Was Rules and Safety. In Those Rules: Effects of Neighbourhood Redevelopment on Criminal Structure. British Journal Criminology, 57(2), 422-40. 
Sampson, R. (2012). Great American City: Chicago and the Enduring Neighbourhood Effect. Chicago, IL: The University of Chicago Press.

Sampson, R., \& Laub, J. (1993). Crime in the Making: Pathways and Turning Points Through Life. Cambridge, MA: Harvard University Press.

Shaw, C., \& McKay, H. (2006). The Chicago School of Criminology: Juvenile Delinquency and Urban Areas. Chicago, UL: The University of Chicago Press.

Song, Z. et al. (2014). The Early Childhood Education of Disadvantaged Children in China. European Early Childhood Education Research Journal, 22(3), 355-65. https://doi.org/10.1080/1350293X.2014.912898.

Wacquant, L. (2008). The State and Fate of the Dark Ghetto at Century's Close. Urban Outcasts: A Comparative Sociology of Advanced Marginality (pp. 43-91). Cambridge, MA: Polity Press.

Wacquant, L. (2016). Revisiting Territories of Relegation: Class, Ethnicity and State in the Making of Advanced Marginality. Urban Studies, 53(6), 1077-88. https://doi.org/10.1177/0042098015613259.

Wang, F. (2005). Organizing Through Division and Exclusion: China's Hukou System. Stanford, CA: Stanford University Press.

Wang, X. (2017). Migration, Schooling Choice, and Student Outcomes in China. Population and Development Review, 43(4), 625-43. https://doi.org//10.1111/padr.12101,

Wirth, L. (2011). Urbanisation as a Way of Life. In R. LeGates, \& F. Stout (Eds.), The City Reader (pp. 115-20). London: Routledge. https://doi.org//10.1086/217913,

Wong, D. et al. (2007). Rural Migrant Workers in Urban China: Living a Marginalised Life. International Journal of Social Welfare, 16(1), 32-40. https://doi.org//10.1111/j.1468-2397.2007.00475.x.

Wong, D. et al. (2009). Correlates of Psychological Wellbeing of Children of Migrant Workers in Shanghai, China. Social Psychiatric Epidemiology, 44(10), 815-24. https://doi.org/10.1007/s00127-009-0003-y,

Wong, D. et al. (2010). The Protective Functions of Relationships, Social Support and Self-Esteem in the Life Satisfaction of Children of Migrant Workers in Shanghai, China. International Journal of Social Psychiatry, 56(2), 143-57. https://doi.org/10.1177/0020764009102755.

Wen, M., \& Lin, D. (2012). Child Development in Rural China: Children Left Behind by Their Migrant Parents and Children of Non-migrant Families. Child Development, 83(1), 120-36. https://doi.org/10.1111/j.1467-8624.2011.01698.x,

Xiao, Y. (2011). The Education of Migrant Workers" Children in China: Lived Inequities and Policies (Doctoral Thesis). University of Calgary, Calgary.

Xu, H., \& Xie, Y. (2015). The Causal Effects of Rural-to-Urban Migration on Children's Well-being in China. European Sociological Review, 31(4), 502-19. https://doi.org/10.1093/esr/jcv009

Young, J. (2013). China's Hukou System: Markets, Migrants and Institutional Change. Basingstoke: Springer.

Yuan, X. et al. (2013). Development of Urban Adaptation and Social Identity of Migrant Children in China: A Longitudinal Study. International Journal of Intercultural Relations, 37(3), 354-65. https://doi.org/10.1016/j.ijintrel.2012.10.002

Zhao, C. et al. (2017). Care for Left-Behind Children in Rural China: A Realist Evaluation of a Community-Based Intervention. Children and Youth Services Review, 82(1), 239-45. https://doi.org/10.1016/j.childyouth.2017.09.034

Zhao, S. et al. (2015). Maternal Parenting and Social, School, and Psychological Adjustment of Migrant Children in Urban China. International Journal of Behavioural Development, 39(6), 541-51. https://doi.org/10.1177/0165025415576815

\section{Copyrights}

Copyright for this article is retained by the author(s), with first publication rights granted to the journal.

This is an open-access article distributed under the terms and conditions of the Creative Commons Attribution license (http://creativecommons.org/licenses/by/4.0/). 